\title{
Obituary
}

\section{David Alan Alexander}

\section{Emeritus Professor of Mental Health, Robert Gordon University, Aberdeen, Scotland}

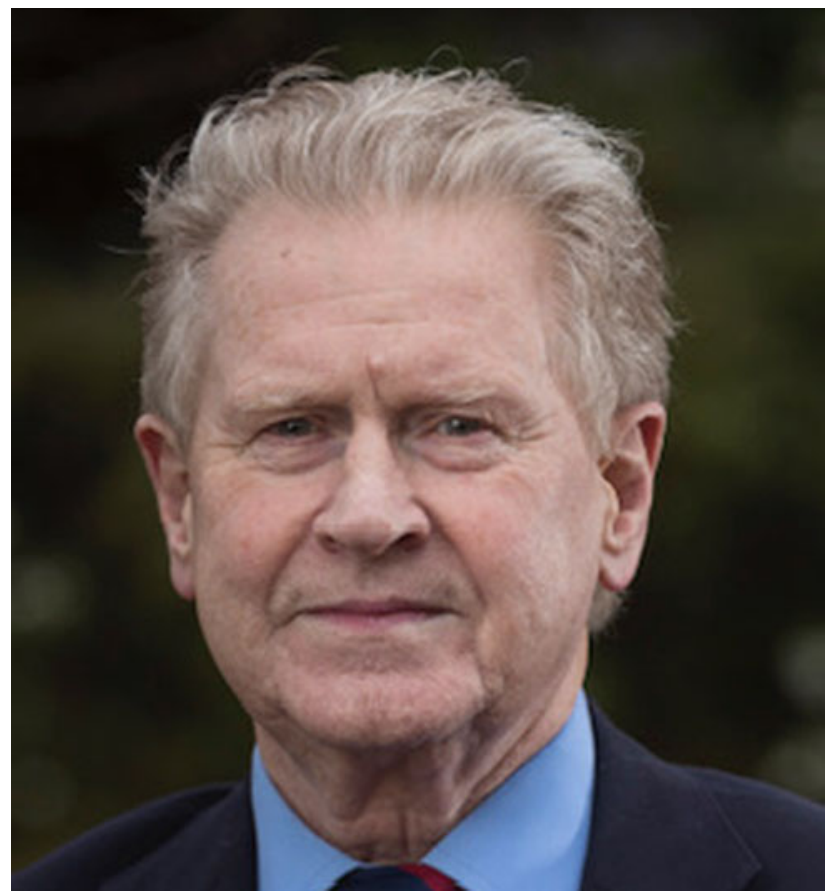

Permission to replicate this figure has been given to the authors by IED Training Solutions.

David Alexander, who died recently aged 76 years, was an outstanding, internationally acclaimed expert in the field of mental health management and policy following major disasters. His involvement in such events began in 1988, with the Piper Alpha disaster. An oil platform in the North Sea had caught fire, with the loss of 167 lives. David was dispatched by helicopter that same night to the fire-fighting support vessel, then deployed with the recovery team at Scapa Flow. Developing a grounded, approachable style, he established rapport with the rescue team and survivors. To those in the field, he offered practical no-nonsense advice. From that early start, his contribution to developing an understanding of trauma and resilience following natural disaster, malevolent acts or armed conflict has been comprehensive and unparalleled. His contributions have been practical, strategic and academic. Strategists, policymakers and victim groups both in the UK and around the world have followed the example of those front-line staff who, recognising his gift to respond to personal need while seeing the 'big picture', sought his advice and counsel.

Prepared by the training he undertook to master the skills of advanced driving and self-defence, he was undaunted by the harshness of conditions in which he often chose to work. Over the past 30 years, he attended the majority of the largest natural disasters or troublesome conflict zones in the world in, for example, China, Nigeria, Croatia, Iraq and Pakistan. Additional overseas beneficiaries of his expertise included the FBI Academy at Quantico; the Russian School of Militia; and the Pakistan Army Academy and School of Military Intelligence. His death was described as a 'national loss' for Pakistan. He was named Distinguished Trauma Visitor in South Africa.

David was appointed by the Department of Health for England to join the international team that wrote the NATO guidance Psychosocial Care for People Affected by Disasters and Major Incidents (2008) and commissioned to generate the evidence base for it. He also contributed to the training of the UK military services, proudly holding the rank of Major in the Royal Army Medical Corps Reserve - though he recently claimed his uniforms had shrunk! As a key member of Admiral, the Lord Boyce's independent scrutiny group and Sir Anthony Newman-Taylor's independent expert medical group, both revising the Armed Forces Compensation scheme, he imparted knowledge with authoritative clarity, academic scrutiny, demand for justice and grammatical exactitude.

He was instrumental in establishing Hostage UK and a number of other agencies supporting civilian and military victims of disasters and conflict. His uniquely caring, insightful, sage yet humorous view of the world underpinned his relentless commitment to supporting the thousands he encountered professionally. Yet he could be forthright when he expressed his views. Holding strong principled views of justice, he always gave succinct definitive opinions, claiming 'no one will ever say l've splinters in my arse from sitting on the fence'.

Born 28 August 1943 to William Drocourt, a commercial manager, and Margaret Jane Alexander (née Torrance) in Ellon, Aberdeenshire, David was educated at George Watson's College, Edinburgh, and Morgan Academy, Dundee. He then read Psychology and Philosophy at St Andrews University, graduating BA (Hons) in 1966. Appointed as a lecturer in a somewhat anarchic Department of Mental Health in Aberdeen (1970) his robustly referenced, engaging lectures inspired many medical students to enter psychiatry, encouraging them to excel during their careers. He was appointed senior lecturer/consultant in 1980 but continued to enhance his own professional development and skills base. While working sessions at Her Majesty's Prison Peterhead, he trained in advanced forensic psychiatry and the additional psychological interventions and hypnosis techniques that he applied in pain management clinics. He published widely in his field, both for the benefit of general practitioners ${ }^{1}$ and for a specialist readership. ${ }^{2,3}$

Having been appointed to a personal professorial chair in 1994 at the University of Aberdeen, he established Scotland's first regional trauma clinic, then in 1999 the Aberdeen Centre for Trauma Research, which transferred with his move to Robert Gordon University 6 years later. For over 20 years, he worked closely with the police academies in Scotland and England, lecturing, advising on hostage negotiation, crisis and trauma management, and terrorism, and 
acting as an expert witness in cases of fatal shootings by firearms officers.

A private and reserved man, David was known for his mischievous, often irreverent sense of humour. He was an accomplished track athlete and rugby player in his youth and a passionate follower of cricket and rugby union. He was regularly frustrated by the failure of his beloved Scotland rugby team to deliver on potential; a view he aired widely. A lifelong educator, mentor, innovator, researcher, strategist and collaborator (initially between psychiatry and psychology, long before it was fashionable), he engaged with patients and survivors as readily as with clinical colleagues, senior military and law enforcement officers, and politicians. A staunch advocate of multidisciplinary clinical training, he was always keen to include unconventional training partners and to build on embedded but underutilised local skills resources.

Following 'retirement' in 2011 David's skill and expertise continued to be in demand, but working pro bono on his own terms with selected military and law enforcement agencies and civilian groups, he continued advising on trauma management and training, mass shootings, hostage-taking, suicide bombing, deradicalisation, and promoting individual and group resilience.

He was embarrassed by awards, but some he cherished. He was elected an Honorary Fellow of the Royal College of Psychiatrists in 2002; and received the Scottish Government's Humanitarian Medal in 2005. In 2016, on being awarded only the third Aberdeen Medico-Chirurgical Society's President's
Medals ever conferred, he quipped 'recognition by yer ain folk is special'. In 2017, he received an Honorary Doctorate of Science from the Abertay University.

David died at home in Aberdeen on 8 January 2020. His self-deprecating, empathic and approachable style, clearly articulated expertise and compassionate human presence in an often inhumane world are sorely missed. He left deep footprints to follow.

\section{References}

1 Alexander DA. Psychological intervention for victims and helpers after disaster. Br J Gen Pract 1990; 40: 345-8.

2 Alexander DA, Klein S. Biochemical terrorism: too awful to contemplate, too serious to ignore. Br J Psychiatry 2003; 183: 491-7.

3 Alexander DA. Early mental health intervention after disasters. Adv Psychiatr Treat 2005; 11: 12-8.

Susan Johnston and Richard Williams

doi:10.1192/bjb.2020.47

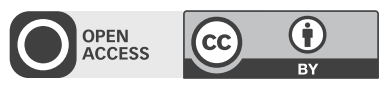

(C) The Authors 2020. This is an Open Access article, distributed under the terms of the Creative Commons Attribution licence (http://creativecommons.org/ licenses/by/4.0/), which permits unrestricted re-use, distribution, and reproduction in any medium, provided the original work is properly cited.

\section{Bulletin}

